\title{
MULTIDIMENSIONAL ASPECTS OF FINAL PURCHASERS' MARKETING ACTIVITY IN THE CONDITIONS OF DYNAMIC MARKET CHANGES
}

\author{
Prof. Agnieszka Izabela Baruk \\ Lodz University of Technology \\ Faculty of Management and Production Engineering \\ Department of Management Systems and Innovation \\ Piotrkowska Street 266, 90-924 Łódź, Poland \\ e-mail: agnieszka.baruk@poczta.onet.pl \\ ORCID: 0000-0003-2864-509X
}

Received 8 January 2020, Accepted 20 March 2020

\begin{abstract}
Research background: The results of the analysis of the world literature on marketing and management indicate a cognitive gap and research one regarding the forms of marketing activity of final purchasers and its image-related and relational aspects as differentiating features. These issues have not been analysed in a theoretical perspective as well as in a research one.

Purpose: The article aims to define the marketing activity of contemporary final purchasers and identify the significance of selected dimensions of this activity as its differentiating features.

Research methodology: To prepare the theoretical part the method of cognitive-critical analysis of the world literature was applied. In order to reduce the identified gaps, empirical research was conducted. To gather primary data a questionnaire survey was used. The collected data was statistically analysed using the Kruskal-Wallis test.

Results: The analysed aspects differentiate forms of respondents' marketing activity to a various degree. A statistically significant differentiation was identified for the greatest number of activities related to the situation whether respondents making purchase decisions take into account the fact that a product has been prepared by an offeror together with purchasers.

Novelty: The originality of the proposed approach is evidenced by the fact that the aspects presented in this article have not been analysed so far, either in theoretical or in practical terms.
\end{abstract}

Keywords: forms of marketing activity, final purchaser, market changes

JEL classification: M31 


\section{Introduction}

Contemporary final purchasers are actively involved in the functioning of the consumer market. The level and scope of their activity is significantly different from the level and scope of purchaser activity in the past. Due to the high activity of contemporary consumers, they are often referred to as engaged, active, and working purchasers (Cova, 2009). Consumers are most often mentioned in relation to their behaviour on the Internet (Tang, Zhang, Wu, 2013), although the increase in purchaser activity is also visible outside the virtual world. All of these definitions of contemporary consumers are used to emphasize their growing readiness to engage in marketing activity and to emphasize the fact that the scope of this activity definitely goes beyond the purchase behaviour of past consumers, who are referred to as passive recipients.

The behaviour of contemporary final purchasers that makes up their marketing activity is on the one hand a consequence of dynamic changes taking place in the marketing environment, and on the other hand it significantly contributes to making this environment more dynamic, for example by redefining relationships between market entities (Roos, Gustafsson, 2011). Thus, the behaviour influences the purchasers themselves, contributing to changes in their attitudes, lifestyle, etc., while determining the functioning of various organizations, including enterprises, which have traditionally played the role of suppliers, and are currently often playing this role together with purchasers. Purchaser activity is characterized by a large variety of a subjective, objective or geographical nature. It is therefore a multidimensional phenomenon, not only market but also economic, social and cultural. The importance of purchaser activity makes it worth identifying its reasons, course, and consequences. The aim of the article is to determine the scope of marketing activity of contemporary final purchasers and to identify the importance of selected areas of this activity as its differentiating features. This article is structured to achieve this purpose. In the second, theoretical, part of the article, results of an analysis of the world literature are presented, which allow the hypotheses to be formed. The third and fourth parts present the methodology of the primary research and its results, respectively. It is followed by the most important conclusions, including the limitations of the research conducted.

\section{Literature review}

The market commitment of contemporary final purchasers, which can be either individual or group in nature (Pagani, Malacarne, 2017), is reflected in their marketing activity. Marketing activity can be defined as all internet and/or off-line attitudes and behaviours, adopted both individually or in a group in order to meet specific material and non-material needs in 
a satisfactory manner. This definition results from the general definition of marketing and its fundamental assumption to best meet the needs and requirements of recipients (Sarkar, Kotler, 2019), which remains unchanged regardless of the evolution of its interpretation.

One of the basic differences between the classical and modern approach to marketing (Darmody, 2009) is the fact that in the modern approach final purchasers actively contribute to meeting their expectations, not only by adopting certain shopping behaviour, but also by manifesting non-shopping behaviour including communication and creation. Thus, purchasers play both the role of recipients and creators of a marketing offer (i.e. product (Banović et al., 2016) and non-product elements, e.g. the brand (Boradjieva, 2017). This makes it possible to give an offer certain features that better meet the expectations of final purchasers (Bhalla, 2016). Knowing this is one of the numerous incentives that encourage final purchasers to engage in marketing activity.

The engagement of final purchasers in marketing activity also results from other reasons, such as an increase in the level of their market awareness, willingness to imitate famous people, willingness to follow specific trends, striving to establish relationships with other entities, willingness to manifest one's talents and experiences, and even hedonistic reasons (Casalo, Flavian, Ibáñez-Sánchez, 2017). Thus, it can be concluded that the active participation of purchasers in marketing activities traditionally undertaken by the offerors themselves is a consequence of changes, especially cultural and social ones that take place on the market, the dynamics of which have been growing particularly clearly in recent decades, among others because of the digitization of many spheres of life. At the same time, the increased engagement of final purchasers leads to changes in their lifestyles, contributing to further market dynamics, which is reflected, among others, in the interpenetration of market roles (Bauer, Gegenhuber, 2015) and the emergence of new forms of meeting specific needs. Therefore, the marketing activity of purchasers on the one hand is extremely diverse, and on the other hand it is a consequence of various factors, being at the same time the cause and catalyst for various market changes. It can therefore be concluded that one of the features of purchaser activity is its multidimensionality.

The increase in the level of commitment makes final purchasers key market actors (Martínez-Cañas, Ruiz-Palomino, Linuesa-Langreo, Blázquez-Resino, 2016). However, the results of the analysis of the literature on the subject indicate that purchaser activity is still considered mainly as a one-dimensional phenomenon, e.g. in relation to only purchase behaviour. The cultural dimension of purchase behaviour has been analysed among others by E.S. Asamoah and M. Chovancová (2016), the religious dimension among others by 
N. Ghodsimaab (2016), and in a social dimension among others by X. Yin, H. Wang, Q. Xia and Q. Gu (2019). Other authors, on the other hand, deal only with purchaser activity on the Internet (e.g. Kowalczuk, 2018; Elida, Rahardjo, Raharjo, Sukirman, 2019). It is true that more and more attention is being paid to purchasers' role as prosumers and to prosumption as a market trend (among others Alderete, 2017; Rayna, Striukova, 2016); however, marketing activity is not analyzed as a multidimensional phenomenon, and focus is not placed on its selected aspects and their significance as its differentiating features.

Therefore, the main goal of this article is to determine the range of marketing activity of contemporary final purchasers and to identify the significance of selected aspects of this activity as its differentiating features. The article also aims to achieve the following specific goals:

G1: to indicate the significance of the ease to make contact with other people as a feature differentiating forms of marketing activity.

G2: to indicate the significance of taking into account the fact that a product has been prepared by a manufacturer together with purchasers when making purchase decisions as a feature differentiating forms of marketing activity.

G3: to indicate the significance of a group of offerors most desirable to cooperate with in the preparation of an offer as a feature differentiating forms of marketing activity.

In order to achieve these goals, three research hypotheses were verified:

H1: the ease of making contact with other people is a feature that statistically significantly differentiates forms of marketing activity.

H2: when making purchase decisions, the fact that a product has been prepared by a manufacturer together with purchasers is a feature that statistically significantly differentiates forms of marketing activity.

H3: a group of offerors most desirable to cooperate with in the preparation of an offer is a feature that statistically significantly differentiates forms of marketing activity.

\section{Research methods}

In order to achieve research goals and to verify the formulated hypotheses, primary research was carried out. It was conducted as part of the research project 2013/11/B/HS4/00430 financed by the National Science Centre. The research proper was conducted in the third quarter of 2015 among 1,200 people representing adult Polish final purchasers from all over Poland. A total of 1,012 completed questionnaires were qualified for a statistical analysis. $61 \%$ of the surveyed population were women, which corresponded to the structure of the general population 
of adult Poles ('Polska w liczbach'). The non-random selection' ${ }^{1}$ of a quota-type sample was applied. The research was direct in nature, requiring the interviewer's personal contact with respondents. This made it possible to obtain a high return rate of completed questionnaires.

The objective scope of the research included the following aspects: 1) self-assessment of the ease of making contact with other people; 2) taking into account the participation of purchasers in the preparation of an offer when making purchasing decisions; 3 ) the indicated group of offerors most desirable to cooperate with; 4) 15 forms of marketing activity of final purchasers. The first two aspects were identified through dichotomous questions that could be answered 'yes' or 'no'. For the question about a group of offerors, a cafeteria of 3 answers was included (producers, traders and service providers). This allowed the total of respondents to be divided into two or three separate groups, respectively. As a result, it was possible to make an analysis to check whether these aspects are features that statistically significantly differentiate the indications of respondents regarding the forms of marketing activity they undertake. Undertaking particular forms of marketing activity was identified by means of the odd Likert scale, which is one of the most fundamental and most commonly used psychometric tools in social sciences (Joshi, Kale, Chandel, Pal, 2015). A five-step variant of this scale was used in the present article, in which 5 stood for 'definitely yes', 4 - 'rather yes', 3 - 'neither yes nor no', 2 - 'rather no', and 1 - 'definitely no'. The forms of marketing activity were selected on the basis of the cognitive and critical analysis of the world literature on the subject and on the basis of unstructured interviews which were carried out before the survey was completed.

The primary data collected during the studies proper were used in further stages of the research process that is a statistical analysis using the Kruskal-Wallis (KW) test. The KW test allows an answer to be found as to whether the diversity in terms of separating individual groups (e.g. respondents' opinions) is statistically significant enough to say that the respondents' opinion determined by the analysed response is significantly different. It is a non-parametric equivalent of ANOVA(Ostertagova, Ostertag, Kovač, 2014). The test checks whether the number of independent results from a group comes from the same population or from a population with the same median. Individual samples do not have to be of the same number. The input data are an n-element statistical sample divided into ' $\mathrm{k}$ ' disjointed groups with numbers ranging from ' $\mathrm{n}_{1}$ ' do ' $\mathrm{n}_{\mathrm{k}}$ '. The higher the KW test values are at a satisfactory level of significance, the greater is the statistically significant diversity.

Statistical analysis was done using the Statistica 8.0 package.

\footnotetext{
1 According to Szreder (2010), it is not always necessary to apply random selection, and more and more often nonrandom selection can even be treated as an opportunity for a researcher.
} 


\section{Research results}

The first analyzed aspect of respondents' marketing activity was the relational dimension. It took the form of the self-assessment of the ease of making contact with other people. The majority of respondents (as many as $85.0 \%$ ) assessed stated that they easily make contact with other people. The results of the Kruskal-Wallis test indicate that this feature statistically significantly differentiates more than half of the analyzed forms of activity (Table 1). For 8 forms of activity, the significance level 'p' has a lower value than the accepted limit value of 0.05 . These include 3 forms of communication behaviour adopted in relationships with other purchasers, 4 forms of behaviour adopted in contacts with offerors, including 3 forms of spontaneous behaviour, and a form of behaviour involving the independent preparation of products that does not require establishing relationships with any entity. Hypothesis H1 is valid for the forms mentioned above.

Table 1. Analysis of the significance of differences between respondents' answers regarding forms of marketing activity undertaken according to the declared ease to make contact with other people

\begin{tabular}{|c|c|c|c|c|}
\hline Forms of marketing activity & Symbol & $\begin{array}{c}\text { Ease of making } \\
\text { contact }\end{array}$ & $\begin{array}{l}\text { KW test } \\
\text { value }\end{array}$ & $\begin{array}{l}\text { Level } \\
\text { of significance } \\
\text { 'p' }\end{array}$ \\
\hline 1 & 2 & 3 & 4 & 5 \\
\hline \multirow{2}{*}{$\begin{array}{l}\text { I eagerly express my opinions about products I use via the } \\
\text { Internet (e.g. on the online forum or on the store's website), } \\
\text { but I do not contact the producer directly }\end{array}$} & \multirow{2}{*}{ a } & yes & 504.78 & \multirow{2}{*}{0.553} \\
\hline & & no & 519.58 & \\
\hline \multirow{2}{*}{$\begin{array}{l}\text { I eagerly express my opinions about products I use without } \\
\text { using the Internet (to friends/family, or directly in the store, } \\
\text { etc.), but I do not contact the producer directly }\end{array}$} & \multirow{2}{*}{$\mathrm{b}$} & yes & 522.45 & \multirow{2}{*}{$\underline{0.000}$} \\
\hline & & no & 419.47 & \\
\hline \multirow{2}{*}{$\begin{array}{l}\text { I eagerly add comments about the products I use to other } \\
\text { consumers' opinions on the Internet }\end{array}$} & \multirow{2}{*}{$\mathrm{c}$} & yes & 510.50 & \multirow{2}{*}{0.350} \\
\hline & & no & 487.19 & \\
\hline \multirow{2}{*}{$\begin{array}{l}\text { I eagerly get acquainted with the opinions of other consum- } \\
\text { ers posted on the Internet about the products I use or intend } \\
\text { to use }\end{array}$} & \multirow{2}{*}{ d } & yes & 514.62 & \multirow{2}{*}{$\underline{0.041}$} \\
\hline & & no & 463.82 & \\
\hline \multirow{2}{*}{$\begin{array}{l}\text { I eagerly get acquainted with the opinions of other consum- } \\
\text { ers, not posted on the Internet, about the products I use or } \\
\text { intend to use (e.g. from friends/family, salesperson, etc.) }\end{array}$} & \multirow[b]{2}{*}{ e } & yes & 523.63 & \multirow{2}{*}{$\underline{0.000}$} \\
\hline & & no & 412.78 & \\
\hline \multirow{2}{*}{$\begin{array}{l}\text { On my own initiative, I eagerly contact producers via the } \\
\text { Internet expressing my opinion/giving advice about the } \\
\text { products I use or intend to use }\end{array}$} & \multirow{2}{*}{$\mathrm{f}$} & yes & 494.41 & \multirow{2}{*}{$\underline{0.000}$} \\
\hline & & no & 578.33 & \\
\hline \multirow{2}{*}{$\begin{array}{l}\text { On my own initiative, I eagerly contact producers without } \\
\text { using the Internet to express my opinion/give advice about } \\
\text { the products that I use or intend to use }\end{array}$} & \multirow[b]{2}{*}{$\mathrm{g}$} & yes & 498.71 & \multirow{2}{*}{$\underline{0.020}$} \\
\hline & & no & 553.94 & \\
\hline
\end{tabular}




\begin{tabular}{|c|c|c|c|c|}
\hline 1 & 2 & 3 & 4 & 5 \\
\hline \multirow{2}{*}{$\begin{array}{l}\text { On my own initiative, I eagerly contact producers in vari- } \\
\text { ous ways via the Internet, asking questions about the prod- } \\
\text { ucts I use or intend to use }\end{array}$} & \multirow{2}{*}{$\mathrm{h}$} & yes & 499.67 & \multirow{2}{*}{$\underline{0.040}$} \\
\hline & & no & 548.55 & \\
\hline \multirow{2}{*}{$\begin{array}{l}\text { On my own initiative, I eagerly contact producers in vari- } \\
\text { ous ways without using the Internet, asking questions about } \\
\text { the products I use or intend to use }\end{array}$} & \multirow[b]{2}{*}{$\mathrm{i}$} & yes & 502.93 & \multirow{2}{*}{0.258} \\
\hline & & no & 530.05 & \\
\hline \multirow{2}{*}{$\begin{array}{l}\text { I eagerly participate in activities/actions organized by com- } \\
\text { panies via the Internet, thanks to which I am a co-creator } \\
\text { of the product or its attributes, e.g. packaging, brand, etc. }\end{array}$} & \multirow[b]{2}{*}{$\mathrm{j}$} & yes & 500.19 & \multirow{2}{*}{0.057} \\
\hline & & no & 545.60 & \\
\hline \multirow{2}{*}{$\begin{array}{l}\text { I eagerly participate in activities/actions organized by com- } \\
\text { panies otherwise than via the Internet, thanks to which I am } \\
\text { a co-creator of the product or its attributes, e.g. packaging, } \\
\text { brand, etc. }\end{array}$} & \multirow[b]{2}{*}{$\mathrm{k}$} & yes & 498.97 & \multirow[b]{2}{*}{$\underline{0.025}$} \\
\hline & & no & 552.49 & \\
\hline \multirow{2}{*}{$\begin{array}{l}\text { I eagerly participate in activities/actions organized by com- } \\
\text { panies via the Internet, thanks to which I am a co-creator } \\
\text { of promotional activities, e.g. advertising slogans, advertis- } \\
\text { ing campaigns, etc. }\end{array}$} & \multirow[b]{2}{*}{1} & yes & 501.04 & \multirow[b]{2}{*}{0.096} \\
\hline & & no & 540.78 & \\
\hline \multirow{2}{*}{$\begin{array}{l}\text { I eagerly participate in activities/campaigns organized by } \\
\text { companies otherwise than via the Internet, thanks to which } \\
\text { I am a co-creator of promotional activities, e.g. advertising } \\
\text { slogans, advertising campaigns, etc. }\end{array}$} & \multirow[b]{2}{*}{1} & yes & 501.02 & \multirow[b]{2}{*}{0.096} \\
\hline & & no & 540.89 & \\
\hline \multirow{2}{*}{$\begin{array}{l}\text { I eagerly participate in activities/actions organized by com- } \\
\text { panies in various ways, thanks to which I am a co-creator } \\
\text { of any other activities/elements of the company, apart from } \\
\text { the product and promotion }\end{array}$} & \multirow[b]{2}{*}{$\mathrm{m}$} & yes & 501.67 & \multirow[b]{2}{*}{0.142} \\
\hline & & no & 537.17 & \\
\hline \multirow{2}{*}{$\begin{array}{l}\text { I eagerly produce products myself (without contacting the } \\
\text { manufacturer whatsoever), for reasons of economy or prac- } \\
\text { ticality }\end{array}$} & \multirow[b]{2}{*}{$\mathrm{n}$} & yes & 523.61 & \multirow{2}{*}{$\underline{0.000}$} \\
\hline & & no & 412.93 & \\
\hline
\end{tabular}

Source: own study.

Image was another dimension of marketing activity included in the analysis. It was considered according to the fact whether respondents making purchase decisions take into account the fact that a product has been prepared by an offeror together with purchasers. The research shows that less than $1 / 3$ of respondents (32.8\%) take this aspect into account. The results of the KW test show that this feature statistically significantly differentiates as many as 14 out of 15 analyzed forms of activity (Table 2). Therefore, for these forms, hypothesis $\mathrm{H} 2$ is true for respondents. The only form for which a statistically significant differentiation has not been identified is the inter-purchase activity of getting acquainted with other consumers' opinions about products not posted on the Internet. 
Table 2. Analysis of the significance of differences between respondents' answers regarding forms of marketing activity according to the fact whether respondents making purchase decisions take into account the fact that a product has been prepared by an offeror together with purchasers

\begin{tabular}{|c|c|c|c|}
\hline $\begin{array}{c}\text { Forms } \\
\text { of marketing } \\
\text { activity }\end{array}$ & $\begin{array}{l}\text { Taking into account the fact that a product has been } \\
\text { prepared by a producer together with purchasers }\end{array}$ & $\begin{array}{c}\mathrm{KW} \\
\text { test value }\end{array}$ & $\begin{array}{l}\text { Level of significance } \\
\text { 'p' }\end{array}$ \\
\hline \multirow{2}{*}{$\mathrm{a}$} & yes & 643.95 & \multirow{2}{*}{$\underline{0.000}$} \\
\hline & no & 439.39 & \\
\hline \multirow{2}{*}{$\mathrm{b}$} & yes & 562.06 & \multirow{2}{*}{$\underline{\mathbf{0 . 0 0 0}}$} \\
\hline & no & 479.37 & \\
\hline \multirow{2}{*}{$\mathrm{c}$} & yes & 612.54 & \multirow{2}{*}{$\underline{0.000}$} \\
\hline & no & 454.73 & \\
\hline \multirow{2}{*}{ d } & yes & 592.47 & \multirow{2}{*}{$\underline{0.000}$} \\
\hline & no & 464.53 & \\
\hline \multirow{2}{*}{$\mathrm{e}$} & yes & 517.17 & \multirow{2}{*}{0.386} \\
\hline & no & 501.29 & \\
\hline \multirow{2}{*}{ f } & yes & 581.23 & \multirow{2}{*}{$\underline{\mathbf{0 . 0 0 0}}$} \\
\hline & no & 470.02 & \\
\hline \multirow{2}{*}{ g } & yes & 575.85 & \multirow{2}{*}{$\underline{\mathbf{0 . 0 0 0}}$} \\
\hline & no & 472.64 & \\
\hline \multirow{2}{*}{$\mathrm{h}$} & yes & 595.20 & \multirow{2}{*}{$\underline{0.000}$} \\
\hline & no & 463.20 & \\
\hline \multirow{2}{*}{$\mathrm{i}$} & yes & 602.09 & \multirow{2}{*}{$\underline{0.000}$} \\
\hline & no & 459.83 & \\
\hline \multirow{2}{*}{$\mathrm{j}$} & yes & 626.55 & \multirow{2}{*}{$\underline{0.000}$} \\
\hline & no & 447.89 & \\
\hline \multirow{2}{*}{$\mathrm{k}$} & yes & 641.37 & \multirow{2}{*}{$\underline{0.000}$} \\
\hline & no & 440.65 & \\
\hline \multirow{2}{*}{1} & yes & 621.58 & \multirow{2}{*}{$\underline{0.000}$} \\
\hline & no & 450.31 & \\
\hline \multirow{2}{*}{1} & yes & 624.34 & \multirow{2}{*}{$\underline{\mathbf{0 . 0 0 0}}$} \\
\hline & no & 448.97 & \\
\hline \multirow{2}{*}{$\mathrm{m}$} & yes & 634.56 & \multirow{2}{*}{$\underline{\mathbf{0 . 0 0 0}}$} \\
\hline & no & 443.98 & \\
\hline \multirow{2}{*}{$\mathrm{n}$} & yes & 453.34 & \multirow{2}{*}{$\underline{0.000}$} \\
\hline & no & 532.45 & \\
\hline
\end{tabular}

Where: the meaning of letters as in Table 1.

Source: own study. 
Table 3. Analysis of the significance of differences between respondents' answers regarding forms of marketing activity according to a group of offerors who are most desirable to cooperate with during preparing an offer

\begin{tabular}{|c|c|c|c|}
\hline $\begin{array}{c}\text { Forms of marketing } \\
\text { activity }\end{array}$ & $\begin{array}{l}\text { Offerors who are most desirable to } \\
\text { cooperate with by respondents }\end{array}$ & KW test value & $\begin{array}{l}\text { Level of significance } \\
\text { 'p' }\end{array}$ \\
\hline 1 & 2 & 3 & 4 \\
\hline \multirow{3}{*}{ a } & producers & 510.93 & \multirow{3}{*}{$\underline{0.014}$} \\
\hline & traders & 532.67 & \\
\hline & service-providers & 455.51 & \\
\hline \multirow{3}{*}{$\mathrm{b}$} & producers & 523.66 & \multirow{3}{*}{$\underline{0.028}$} \\
\hline & traders & 505.02 & \\
\hline & service-providers & 460.91 & \\
\hline \multirow{3}{*}{$\mathrm{c}$} & producers & 512.06 & \multirow{3}{*}{$\underline{0.017}$} \\
\hline & traders & 530.39 & \\
\hline & service-providers & 455.71 & \\
\hline \multirow{3}{*}{$\mathrm{d}$} & producers & 528.67 & \multirow{3}{*}{$\underline{0.030}$} \\
\hline & traders & 485.72 & \\
\hline & service-providers & 476.11 & \\
\hline \multirow{3}{*}{$\mathrm{e}$} & producers & 522.26 & \multirow{3}{*}{0.161} \\
\hline & traders & 490.54 & \\
\hline & service-providers & 487.54 & \\
\hline \multirow{3}{*}{$\mathrm{f}$} & producers & 507.94 & \multirow{3}{*}{0.221} \\
\hline & traders & 523.32 & \\
\hline & service-providers & 478.88 & \\
\hline \multirow{3}{*}{$\mathrm{g}$} & producers & 509.68 & \multirow{3}{*}{0.004} \\
\hline & traders & 536.69 & \\
\hline & service-providers & 452.94 & \\
\hline \multirow{3}{*}{$\mathrm{h}$} & producers & 515.93 & \multirow{3}{*}{0.218} \\
\hline & traders & 510.07 & \\
\hline & service-providers & 475.88 & \\
\hline \multirow{3}{*}{$\mathrm{i}$} & producers & 505.87 & \multirow{3}{*}{0.358} \\
\hline & traders & 522.70 & \\
\hline & service-providers & 485.93 & \\
\hline \multirow{3}{*}{$\mathrm{j}$} & producers & 516.42 & \multirow{3}{*}{$\underline{0.048}$} \\
\hline & traders & 517.80 & \\
\hline & service-providers & 462.41 & \\
\hline \multirow{3}{*}{$\mathrm{k}$} & producers & 524.35 & \multirow{3}{*}{$\underline{0.029}$} \\
\hline & traders & 502.34 & \\
\hline & service-providers & 463.03 & \\
\hline
\end{tabular}




\begin{tabular}{|c|c|c|c|}
\hline 1 & 2 & 3 & 4 \\
\hline \multirow{3}{*}{1} & producers & 520.08 & \multirow{3}{*}{0.251} \\
\hline & traders & 494.07 & \\
\hline & service-providers & 488.49 & \\
\hline \multirow{3}{*}{1} & producers & 507.55 & \multirow{3}{*}{0.945} \\
\hline & traders & 509.69 & \\
\hline & service-providers & 501.20 & \\
\hline \multirow{3}{*}{$\mathrm{m}$} & producers & 517.19 & \multirow{3}{*}{0.397} \\
\hline & traders & 490.32 & \\
\hline & service-providers & 502.85 & \\
\hline \multirow{3}{*}{$\mathrm{n}$} & producers & 523.88 & \multirow{3}{*}{0.120} \\
\hline & traders & 491.48 & \\
\hline & service-providers & 481.32 & \\
\hline
\end{tabular}

Where: the meaning of letters as in Table 1.

Source: own study.

The last dimension of respondents' marketing activity taken into account in the analysis was the subjective aspect related to offerors, although it also has the features of a relational dimension. Given the type of offerors, respondents would most like to cooperate with producers $(53.6 \%)$, while the lowest percentage of respondents would like to cooperate with service providers $(18.2 \%)$. The remaining part of respondents $(28.2 \%)$ would most like to undertake joint marketing activities with traders. As for the results from Table 3, one can speak about statistically significant differentiation according to a group of offerors who are most desirable to cooperate with when preparing an offer for 6 forms of activity. These forms include 4 forms of inter-purchase communication activity and 2 forms of creative activity inspired by offerors undertaken in relationships between respondents and offerors.

\section{Conclusions}

Based on the presented considerations, it can be stated that the selected forms of marketing activity reflecting its relational, image-related and subjective dimensions are features that statistically significantly differentiate the number of respondents' marketing activity. However, it is worth noting that some of the analyzed forms are subject to differentiation according to each of these three dimensions. These include 2 forms of inter-purchase activity marked with the symbols ' $b$ ' and ' $d$ ', and a form of creative activity undertaken in relationships with offerors and 
inspired by them, i.e. participation in activities organized by companies in a different way than via the Internet, thanks to which the respondent was a co-creator of the product.

The identification of the diversity of marketing activity of final purchasers has a cognitive and applicability value. It allows the existing knowledge to be supplemented. To the most important practical implications one can count the fact that the knowledge of identified diversity makes it easier for offerors to undertake the right actions that would effectively stimulate final purchasers to engage in marketing activities by displaying their communication and creative abilities and skills. Of course, the research has certain limitations, which include their subjective and objective scope. The research included only representatives of Polish adult final purchasers, and the analysis took into account a limited set of several forms of activity and its selected aspects. These limitations will be eliminated in further research concerning the activity of contemporary purchasers, which are planned by the author. It is also worth adding that the article presents only a fragment of the research results, which is a consequence of the necessity to comply with publishing requirements.

\section{References}

Alderete, M.V. (2017). The Age of Prosumerism: Some Micro-Economic Analysis. Journal of Theoretical and Applied Electronic Commerce Research, 12 (3), 1-12. DOI: 10.4067/ S0718-18762017000300002.

Asamoah, E.S., Chovancová, M. (2016). The Effect of Cultural Orientation on the Purchasing Decisions of Consumers: a Cross Cultural Comparative Study. International Journal of Contemporary Management, 15 (1), 7-32. DOI: 10.4467/24498939IJCM.16.001.4834.

Banović, M., Krystallis, A., Guerrero, L., Reinders, M.J. (2016). Consumers as co-creators of new product ideas: An application of projective and creative research techniques. Food Research International, 87, 211-223. DOI: 10.1016/j.foodres.2016.07.010.

Bauer, R.M., Gegenhuber, T. (2015). Crowdsourcing: Global search and the twisted roles of consumers and producers. Organization, 22 (5), 661-681. DOI: 10.1177/1350508415585030.

Bhalla, G. (2016). Collaboration and Co-Creation: The Road to Create Value. The Marketing Journal. Retrieved from: http://www.marketingjournal.org/collaboration-and-co-creationthe-road-to-creating-value.

Boradjieva, M. (2017). 3 Ways Consumers Co-Create Brands. Digital Marketing Magazine, Retrieved from: http://digitalmarketingmagazine.co.uk/digital-marketing-features/3-waysconsumers-co-create-brands. 
Casalo, L.V., Flavian, C., Ibáñez-Sánchez, S. (2017). Understanding Consumer Interaction on Instagram: The Role of Satisfaction, Hedonism, and Content Characteristics. Cyberpsychology, Behavior and Social Networking, 20 (6), 369-375. DOI: 10.1089/cyber.2016.0360.

Cova, B., Dalli, D. (2009). Working Consumers: The Next Step in Marketing Theory? Marketing Theory, 9 (3), 315-339. DOI: 10.1177/1470593109338144.

Darmody, A. (2009). Value Co-Creation and New Marketing. Technology Innovation Management Review. Retrieved from: https://timreview.ca/article/302.

Elida, T., Rahardjo, W., Raharjo, A., Sukirman, E. (2019). Online Shopping: What Factors Determine Consumers to Buy? Management Studies, 7 (3), 238-246. DOI: 10.17265/23282185/2019.03.007.

Ghodsimaab, N. (2016). Influence of Religion on Consumer Behavior (Shopping Behavior and Consumption Behavior) Among Muslim and Hindu Customers. International Research Journal of Multidisciplinary Studies, 2 (5), 1-4.

Polska w liczbach ('Poland in numbers'). Retrieved from: http://www.polskawliczbach. pl/\#ixzz4F3Nog11N.

Joshi, A., Kale, S., Chandel, S., Pal, D.K. (2015). Likert Scale: Explored and Explained. British Journal of Applied Science \& Technology, 7 (4), 396-403. DOI: 10.9734/ BJAST/2015/14975.

Kowalczuk, J. (2018). The Evolvement of Online Consumer Behavior: The ROPO and Reverse ROPO Effect in Poland and Germany. Journal of Management and Business Administration. Central Europe, 26 (3), 14-29. DOI: 10.7206/jmba.ce.2450-7814.233.

Martínez-Cañas, R., Ruiz-Palomino, P., Linuesa-Langreo, J., Blázquez-Resino, J. (2016). Consumer Participation in Co-creation: An Enlightening Model of Causes and Effects Based on Ethical Values and Transcendent Motives. Frontiers Psychology, 7, 793. DOI: 10.3389/ fpsyg.2016.00793.

Ostertagova, E., Ostertag, O., Kovač, J. (2014). Methodology and Application of the KruskalWallis Test. Applied Mechanics and Materials, 611, 115-120. DOI: 10.4028/www.scientific.net/AMM.611.115.

Pagani, M., Malacarne, G. (2017). Experiential Engagement and Active vs. Passive Behavior in Mobile Location-based Social Networks: The Moderating Role of Privacy. Journal of Interactive Marketing, 37, 133-148. DOI: 10.1016/j.intmar.2016.10.001.

Rayna, T., Striukova, L. (2016). Involving Consumers: The Role of Digital Technologies in Promoting 'Prosumption' and User Innovation. Journal of the Knowledge Economy, 7, 1-20. DOI: $10.1007 / \mathrm{s} 13132-016-0390-8$.

Roos, I., Gustafsson, A. (2011). The influence of active and passive customer behavior on switching in customer relationships. Managing Service Quality, 21 (5), 448-464. DOI: 10.1108/09604521111159771. 
Sarkar, Ch., Kotler, Ph. (2019). Ecosystem Marketing: The Future of Competition. The Marketing Journal. Retrieved from http://www.marketingjournal.org/ecosystem-marketing-thefuture-of-competition-christian-sarkar-and-philip-kotler.

Szreder, M. (2010). Losowe i nielosowe próby w badaniach statystycznych. Przegląd Statystyczny, 4, 168-174.

Tang, J., Zhang, P., Wu, P.F. (2013). Passive or Active: Understanding Consumers' Behavioral Responses to Online Advertising. PACIS 2013 Proceedings, 188. Retrieved from: https:// aisel.aisnet.org/pacis2013/188.

Yin, X., Wang, H., Xia, Q., Gu, Q. (2019). How Social Interaction Affects Purchase Intention in Social Commerce: A Cultural Perspective. Sustainability, 11 (8), 2423. DOI: 10.3390/ su11082423. 